\title{
Phytolith taphonomy: a comparison of dry ashing and acid extraction on the breakdown of conjoined phytoliths formed in Triticum durum
}

\section{Introduction}

Phytoliths are composed of hydrous silica which is taken up as monosilicic acid by plants through their roots into the vascular system during transpiration and deposited in inter and intra cellular spaces. Because they are inorganic, phytoliths are durable and survive well in both aerobic and anaerobic conditions. Phytoliths can provide an overview of the floral record at an archaeological site when macro-botanical remains are scarce or absent and have been used to differentiate between the parts of plants present in assemblages providing information on crop processing (Rosen 1999; Harvey and Fuller 2005). In some cases, phytolith preservation is so complete that clear phytolith impressions or artefacts such as reed matting and baskets are visible in situ (Rosen 2005). More controversially, phytoliths have been used to differentiate between wild and domesticated strains of plants (e.g. rice, Pearsall et al 1995; Zhao et al 1998; Piperno et al. 2000, 2002, Piperno and Stothert 2003; and maize, Pearsall et al 2003; Piperno 1988; Piperno and Pearsall, 1993) and to identify wheat and barley phytoliths to species level (Ball et al 1996, 1999, 2001). Phytoliths can provide a record of plant management practices; for instance, Pearsall and Trimble (1984) used the ratios of monocot and dicot phytoliths as evidence for deforestation and the creation of terraced field in Hawaii (Pearsall and Trimble 1984).

However, although phytoliths are inorganic they are susceptible to taphonomic processes that affect their condition and preservation. Little work has been conducted on phytolith taphonomy but it is undoubtedly a topic that warrants investigation, 
particularly as taphonomic changes to phytolith assemblages may ultimately skew interpretation. In this paper, I investigate the impact that laboratory processing methods have on conjoined or multi-celled phytoliths. This is important because it has been proposed that the frequency and size of multi-celled emmer wheat phytoliths can be used as an indicator of the amount of water the plants received during growth in arid or semi-arid regions (Rosen and Weiner 1994).

\section{Taphonomic processes affecting phytoliths}

Phytoliths can be transported by wind or water which may result in pitting and corrosion of single celled forms and breakdown of conjoined or multi-celled forms. There are many examples of phytoliths being transported over vast distances by wind, perhaps the most famous being Charles Darwin’s account of phytoliths being carried by wind from Africa to the Atlantic Ocean (Darwin 1846). Phytoliths recovered from archaeological sites may have been consumed either by animals or humans and in the case of the latter the plants may have undergone extensive processing and cooking prior to consumption.

Post burial phytoliths are affected by soil conditions and it has been documented that phytoliths react adversely to alkaline conditions and may dissolve in pHs of nine or above (Krauskopf 1956; Jones and Handreck 1967; Bartoli and Wilding 1980). Wilding and Drees (1974) conducted experiments to measure the dissolution rates of phytoliths in heated sodium hydroxide and found that the rate of dissolution was dependent on taxa and was ten to fifteen times greater in phytoliths from trees than in those from grasses (Wilding and Drees 1974). 
Illuviation is another taphonomic process that should be considered. Piperno (1985) found that phytoliths did not experience much downward movement in tropical silts and clays and a similar result was reported by Kalisz and Stone (1984) in their studies of phytoliths in porous sands in Florida. However, Hallsworth and Waring (1964) found that phytoliths were washed from the A horizon into the B horizon in sediments in New South Wales indicating that downward movement of phytoliths in sediments is possible (Hallsworth and Waring 1964).

Phytoliths undergo further taphonomic processes during laboratory processing. The method used to extract phytoliths from soils varies according to the preference of the analyst. However, in order to isolate phytoliths, coarse particles (i.e sand and larger sized silts), carbonates and clays are removed, and phytoliths are separated from any remaining material using heavy liquid. Finally, they are mounted onto a microscope slide for analysis. During this process they will usually be subjected to: sieving, immersion in $10 \%$ hydrochloric acid, burning in a muffle furnace at temperatures of approximately $500^{\circ} \mathrm{C}$ or, alternatively, some form of acid extraction, and centrifugation. The full impact of these procedures on the resulting phytolith assemblage remains unknown.

\section{The taphonomic effect of processing on phytoliths from modern plants}

In this study I explore the taphonomic effects of processing methods used to extract phytoliths from modern plants. The two methods most commonly used are dry ashing and acid extraction (although a newer method involving microwave digestion has been proposed (Parr et al 2001a). Dry ashing has been practiced since at least 1861 
(Mohl 1861) and was used by Molisch (1920) and Policard (1923) to prepare histological samples. Dry ashing involves burning the plant material in a muffle furnace in order to remove organic matter and isolate phytoliths whereas acid extraction, or wet-ashing, uses acid to eliminate organic matter. Acid extraction was first developed by Zimmerman at the beginning of the last century (Zimmerman 1901) but was not widely used until fifty years later (Parry and Smithson 1957; Jones and Milne 1963).

Jones and Milne (1963) compared the results of dry ashing and acid extraction on phytoliths from oats (Avena sterilis). For the dry ashed samples, they divided them into two batches, and burnt the first batch for twelve hours at $450^{\circ} \mathrm{C}$ and the second at $550^{\circ} \mathrm{C}$. They found that the phytolith assemblages produced using the dry ashing method contained carbon and greater quantities of $\mathrm{Na}, \mathrm{K}, \mathrm{Ca}, \mathrm{Mg}, \mathrm{Mn}$, and Fe than the assemblage produced by acid extraction. They also discovered that both methods caused dehydration; the dry ashed phytoliths lost water during heating twice, firstly at temperatures of between $60^{\circ} \mathrm{C}$ and $150^{\circ} \mathrm{C}$ and secondly at $570^{\circ} \mathrm{C}$ to $670^{\circ} \mathrm{C}$. The phytoliths from the acid extraction lost water once at $120^{\circ} \mathrm{C}$. The phytoliths from the dry ashed samples consisted of "large composites" which were crushed prior to examination while the acid extraction produced isolated phytoliths though the authors state that if the samples had not been crushed during mounting there would have been more "composite particles" (Jones and Milne 1963: 213). Fusion was found in the dry ashed phytoliths but it is not clear from the paper if this occurred in both the batch burnt at $450^{\circ} \mathrm{C}$ as well as the one burnt at $550^{\circ} \mathrm{C}$. The surface area of the phytoliths 
was smaller in the dry ashed samples than in those from the acid extraction (Jones and Milne 1963).

The issue of conjoined phytoliths was addressed by Fujiwara who, it is reported, crushes the ash resulting from dry ashing in order to obtain disarticulated phytoliths (Fujiwara pers comm cited in Bowdery 1989:172). Dry ashing was used by Jones and Beavers (1964) in their study of phytoliths from Illinois soils. They observed that dry ashing could cause fusion of phytoliths during heating, though they do not state what temperature they employed (Jones and Beavers 1964). Raeside (1970) found that dry ashing at $600^{\circ} \mathrm{C}$ produced a greater number of weakly silicified phytoliths than acid digestion (Raeside 1970: 125) Labouriau (1983) reports no difference between phytoliths extracted from Casearia using a combination of dry ashing at $800^{\circ} \mathrm{C}$ and acid extraction while Pearsall (1989) found some shrinkage in short cell maize phytoliths dry ashed at $500^{\circ} \mathrm{C}$ to $600^{\circ} \mathrm{C}$ (Pearsall 1989). Similarly researchers have reported problems with acid extraction, for example differential rates of digestion for different plant parts, loss of phytoliths during processing, and the undesirability of using noxious chemicals (Pearsall 1989; Parr et al 2001b)

Parr et al (2001b) directly compared the effect of dry ashing and acid extraction on single celled phytoliths. They conducted two different tests on the phytoliths from both extractions. Firstly, they compared the size of bilobates to determine if shrinkage had occurred and secondly the curvature of long cells to test for warping. They found no significant difference between the two assemblages with some species being more curved and shrunken from dry ashing and some from acid extraction. They attribute 
these differences to "the natural range of variability in the phytolith residues themselves” (Parr et al 2001b: 882). They compared the weight percent of phytoliths from the two processing methods and found that the weight percent of the phytoliths produced using acid extraction was $63.7 \%$ greater than the dry ashed samples. They suggest that this difference is due to a failure in oxidation of some plant material which skewed their results (Parr et al 2001b). They conclude that dry ashing “provides clean, lucid, disarticulated and in situ phytolith assemblages more effectively than does the wet ashing method” Parr et al 2001b: 884).

\section{Multi-celled phytoliths and irrigation}

The effect of wet and dry ashing procedures on modern plant samples is important for phytolith research because it could potentially have an impact on a method for identifying irrigation that was proposed by Rosen and Weiner (1994). They suggest that past water availability in arid and semi-arid regions can be inferred from the number of conjoined cells in multi-celled phytoliths formed in emmer wheat (Triticum dicoccum) (Rosen and Weiner 1994). The formation of large multi-celled phytoliths is presumed to be the result of elevated rates of silica precipitation due to increased transpiration rates in plants grown in arid and semi-arid regions, particularly when grown in moist alluvial soils which Rosen and Weiner (1994) suggest have a greater amount of available soluble silica in the soil water. This finding was subsequently supported by the work of Webb and Longstaffe (2002) who report that the weight percent of phytoliths in Prairie grass (Calamovilfa longifolia) was higher in plants grown in arid conditions than those grown in regions with a high relative humidity (Webb and Longstaffe, 2002). 
This innovative research conducted by Rosen and Weiner (1994) was based on crop growing experiments conducted in Gilat, Israel. In these experiments emmer wheat was planted in two plots each measuring approximately $3 \mathrm{~m} \times 1 \mathrm{~m}$. One of these was irrigated the other unirrigated. The rainfall for the growing season was $224 \mathrm{~mm}$ and the irrigated plot received an additional $200 \mathrm{~mm}$ of water. Phytoliths were extracted using acid extraction following the methodology of Piperno (1988:125) (Rosen and Weiner 1994: 127). Rosen and Weiner (1994) observed that the phytoliths grown under irrigation not only had a greater yield of phytoliths but also a greater number of conjoined cells. They report that the percentage of phytoliths with ten or more conjoined cells was only $2.1 \%$ for the unirrigated plants but $13 \%$ in the irrigated plants (Rosen and Weiner 1994). A similar pattern was evident from bread wheat, although the difference between irrigated and unirrigated samples was not as marked and failed to be statistically significant. It is important to determine if this result is consistent with all species of wheat because it is not usually possible to identify cereals to species level using phytoliths. Ball et al (1996) suggest that morphological size differences can allow wheat phytoliths to be identified to species level but this has yet to be embraced by all phytolith researchers (Ball et al 1996).

Rosen and Weiner (1994) propose that when dealing with archaeological samples from arid and semi-arid regions, the presence of at least $10 \%$ of phytoliths with ten or more conjoined cells, or any phytoliths with one hundred or more conjoined cells, provides an indication of past irrigation. This was used to infer that irrigation had been used for growing emmer wheat at two Chalcolithic sites in the northern Negev, 
Gilat and Shiqmim (Rosen and Weiner 1994). If this result is consistent in all wheat species and if it can be demonstrated that conjoined phytoliths are unaffected by taphonomy then this method is invaluable to archaeobotanists working in arid and semi-arid regions.

In order to explore this idea more fully and build on the work of Rosen and Weiner (1994) crop growing experiments were set up in Jordan as part of the Water, Life and Civilisation project based at the University of Reading. Mithen et al (2008) explains fully the nature of these experiments but the main objective was to test if the methodology of Rosen and Weiner (1994) is consistent in different growing conditions and with crops other than emmer wheat. As a result durum wheat, common barley and sorghum were grown at three different crop growing stations in Jordan under a variety of irrigation regimes. The durum wheat analysed in this paper is from the first year of crop growing (2005 to 2006) conducted at Kherbet as-Samra on the Jordanian Plateau.

\section{Objective}

This paper aims to explore the effect that phytolith extraction from modern plants may have on conjoined or multi-celled phytoliths. This will be achieved by comparing the results from dry ashing, acid extraction and a combination of the two procedures on durum wheat plants grown under the same environmental conditions to assess if the phytolith assemblages produced by the two methods are different. In addition, the weight percent of the samples from the dry ashing and the acid extraction will be compared. This was an initial experiment to test if any differences could be observed 
and future experiments, using a wider range of processing methods, are planned for the future.

\section{Methodology}

\section{Field methods}

A native land race of durum wheat (ACSAD 65) was grown in irrigated conditions at an NCARE (National Centre for Agricultural Research and Enterprise) crop growing station in Kherbet as-Samra, Jordan. Kherbet as-Samra is located to the northeast of Amman, on the Jordanian plateau, and has an annual rainfall of approximately $150 \mathrm{~mm}$ per year. The plot measured $5 \mathrm{~m} \times 5 \mathrm{~m}$ and a drip irrigation system was used which had eight lines (i.e. water pipes) and a $60 \mathrm{~cm}$ spacing between each line. There was a $40 \mathrm{~cm}$ spacing between the drippers on each pipe. Reclaimed waste water was used for irrigation which was tested before the experiments began and was found to be within the Jordanian standards for water use in crop irrigation. The growing season ran from November until May 2005 to 2006 and the overall rainfall during this period was $87.70 \mathrm{~mm}$. An additional $245.1 \mathrm{~mm}$ of water was added to the plot which was monitored on a weekly basis and no chemical weed killers, pesticides or fertilisers were employed. The plot was harvested in May 2006. Approximately twenty to thirty plants were sampled, using a diagonal $50 \mathrm{~cm}$ grid system to get a representative sample and to avoid edge affect. The plants were then exported to the University of Reading for analysis.

\section{Laboratory methods}


Twenty plants from across the plot were processed for phytoliths, These were then processed using three different methods. 1) ten using the dry ashing method; 2) ten using acid extraction; 3) using both these methods, first dry ashing and then acid extraction. Initially all plants were washed three times in distilled water and dried in a drying cupboard at $30{ }^{\circ} \mathrm{C}$ before following the methodologies outlined in table 1 . The phytoliths that underwent both methods were processed first using steps one to thirteen of the dry ashing method and then five to twenty-two of the acid extraction method. The methodology followed Piperno (2006: 97-98). After extraction 0.1mg of phytoliths were mounted per sample onto a microscope slide using the mounting agent Entellan.

\section{Counting}

Slides were counted using a Leica DME at x 400. Over 300 forms were counted per slide. Phytoliths were counted according to the number of dendritics in each conjoined form (a clicker counter was used to aid this process) and the following broad counting categories were used: single cell, 2 to 5, 6 to10, 11 to15, 16 to 20, 21 to 30,31 to 50,51 to 70,71 to 100,101 to 150,151 to 200,201 to 250,251 to 300 , $301>$.

\section{Results}

Table 2 shows the average result based on ten samples for each of the processing methods. From this it is clear that acid extraction produces a greater percentage of single dendritic cells than dry ashing with $97.5 \%$ of phytoliths being single cells. This 
contrasts with the dry ashed samples which had fewer single celled varieties, $41.8 \%$, and consisted of phytoliths from all categories, the largest of which, 301 or more conjoined cells, comprised $10.2 \%$ of the total assemblage. The samples that had first been dry ashed and then acid extracted were similar to the dry ashed assemblage.

Figure 1 shows the weight percent of phytoliths derived from the two different methods. This figure illustrates that dry ashing results in a greater weight percent of phytoliths, 5.4\%, than acid extraction which produced an average of only $3.4 \%$. The result for the acid extraction is comparable to Rosen and Weiner's results for the weight percent of husks from the acid extracted irrigated emmer wheat phytoliths from plants grown in Gilat which had a mean of 3.86\%. However, the durum wheat from irrigated fields at Beit Qama, Israel had a much greater weight percent with $13.71 \%$ (Rosen and Weiner 1994). Images of the phytoliths from these samples can be seen in figure 2 and provide a good visual demonstration of the differences in the assemblages.

\section{Discussion}

This comparison of the effects that these processing methods have on the breakdown of conjoined phytoliths or multi-cells demonstrates that the acid extraction employed in this experiment causes a greater breakdown of conjoined phytolith forms than dry ashing, while the combination of both methods produced a similar result to dry ashing. In addition, the dry ashing method produced a greater number of poorly silicified phytoliths than acid extraction as found by Raeside (1970). From this it is 
clear that one (or possibly both) of these methods causes a taphonomic change to the structure of conjoined phytoliths.

One explanation is that the oxidation of the organic matter during acid extraction forces the phytoliths apart and causes a mechanical breakdown of conjoined forms that does not occur with dry ashing. The reason why phytoliths that underwent both treatments were unaffected could be because the organic matter had already been removed in the muffle furnace. Alternatively it may be that dry ashing causes the silica to dehydrate as proposed by Jones and Milne (1963) causing fusion between forms resulting in a stronger structure. Rosen (pers comm. 2008) suggests that the dry ashed samples may retain silica gel which is lost during acid extraction. If this is the case the chemical structure of the gel could change during heating, dehydrating and holding the phytoliths together.

This finding has implications for the use of the methodology proposed by Rosen and Weiner (1994); if dry ashing does cause an increase in fusion then an understanding of the past history of the archaeological contexts sampled is crucial for the application of this methodology. For example, if phytolith samples are taken from a hearth it can be assumed that these plant remains have been burned and so the number of conjoined forms should be more comparable with modern samples from dry ashing. However, if the phytoliths appear to come from a deposit that has not undergone burning then the conjoined forms would be more comparable with those that have been processed using acid extraction. 
If the acid extraction method employed in this experiment causes multi-celled phytoliths to breakdown then this raises concerns for the use of multi-celled cereal phytoliths as indicators of irrigation because it demonstrates that conjoined phytoliths are not stable but can be subject to taphonomic breakdown which could occur at any point between formation and analysis. Further work is planned to test if other chemical digestion methods produce similar results or if this finding is specific to this particular methodology. The results presented in this paper have repercussions for the processing of archaeological sediments because either heating in a muffle furnace or oxidation using nitric acid is usually employed to remove organic matter from the sediment which could cause changes to the phytoliths within.

\section{Conclusion}

A comparison of the number of conjoined cells found in irrigated wheat in ten samples that were dry ashed and ten samples that were processed using an acid extraction demonstrates that either one or both of these methods causes a change in the number of conjoined forms. This has implications for the use of emmer wheat phytoliths as indicators of irrigation and for phytolith taphonomy as a whole. Further research is needed to explore the full extent of multi-celled phytolith breakdown and to establish which processing method, both modern and archaeological, provides the truest reflection of the original phytoliths. 
Ball, T., Gardner, J.S., Brotherson, J.D. 1996. Identifying phytoliths produced by the inflorescence bracts of three species of wheat (Triticum monococcum L., T. Dicoccon Schrank., and T. aestivum L.) using computer-assisted image and statistical analyses. J Archaeol Sci. 23, 619-632

Ball, T.B., Gardner, J.S., Anderson, N. 1999. Identifying Inflorescence Phytoliths from selected Species of Wheat (Triticum monococcum, T. dicoccon, T. dicoccoides, and T. aestivum) and Barley (Hordeum vulgare and H. spontaneum) (Gramineae). American Am J Bot 86, 1615-1623.

Ball, T.B., Gardner, J.S., Anderson, N. 2001 An approach to Identifying Inflorescence Phytoliths from selected Species of Wheat and Barley in: Meunier, J.D., Colin. F. (Eds.), Phytoliths: Applications in Earth Sciences and Human History, A. A. Balkema Publishers, Lisse, Netherlands, pp. 289-301

Bartoli, F., Wilding, L.P. 1980 Dissolution of biogenic opal as a function of its physical and chemical properties. Soil Sci Soc Am J 44, 873-878

Bowdery, D. 1989 Phytolith analysis: introduction and applications in: Beck, S., Clarke, W., Head, A. (Eds.), Plants in Australian Archaeology. Brisbane, Watson Ferguson \& Company, pp.161-186

Darwin, C. 1846. An account of the fine dust which often falls on vessels in the Atlantic Ocean. Q J Geol Soc Lond 22, 26-30 
Hallsworth, E.G., Waring, H.D. 1964 Studies in pedogenesis in New South Wales, VIII. An alternative hypothesis for the formation of the solodized-solenetz of the Pilligia District. J Archaeol Sci 15, 158-177

Harvey, E.L., Fuller, D. G. 2005. Investigating crop processing using phytolith analysis: the example of rice and millets. J Archaeol Sci 32, 739-752

Jones, R.L., Beavers, A.H. 1964. Aspects of caternary and depth distribution of opal phytoliths in Illinois soils. Soil Sci Soc Am Proc 28, 413-416

Jones, L.H.P., Handreck, K.A. 1967. Silica in soils, plants and animals. Adv Agron 19, $107-149$

Jones, L.H.P., Milne, A.A. 1963. Studies of silica in the oat plant: I-Chemical and physical properties of the silica. Plant Soil 18, 207-220

Kalisz, P.J., Stone, E.L. 1984. The Longleaf Pine islands of the Ocala National Forest, Florida: A soil study. Ecology 65, 1743-1754

Krauskopf, K.B. 1956. Dissolution and precipitation of silica at low temperatures.

Geochim Cosmochim Acta 10, 1-26

Labouriau, L. 1983. Phytolith work in Brazil: a mini review. Phytolitharien Newsletter 2, 6-10 
Mithen, S.J., Jenkins, E., Jamjoum, K., Nuimat, S., Nortcliff, S., Finlayson B. 2008. Experimental Crop Growing in Jordan to Develop A Methodology for the Identification of Ancient Crop Irrigation. World Archaeol: 40,7-25

Mohl, H.Von. 1861. Uber das Kieselskelett lebender pflanzenzellen. Botanische Zeitung 19,209-215

Molisch, H. 1920. Aschenbild und pflanz enverwandtschaft. Sitzungsberichte Akademie der Wissenschaften Abhandlungen 1, 129,261-294

Parr, J.F., Dolic, V., Lancaster, G., Boyd, W.E. 2001a. A microwave digestion method for the extraction of Phytoliths from herbarium specimens. Rev Palaeobotany Palynology 116, 203-212

Parr, J.F., Lentfer, C.J., Boyd, W.E. 2001b. A comparative analysis of wet and dry ashing techniques for the extraction of phytoliths from modern plant material. $J$ Archaeol Sci 28, 875-886

Parry, D.W., Smithson, F. 1957. Detection of opaline silica in grass leaves. Nature 179, 975-976

Pearsall, D.M. 1989. Paleoethnobotany: A handbook of procedures. Academic Press, San Diego 
Pearsall, D.M., Chandler-Ezell, K., Chandler-Ezell, A. 2003. Identifying Maize in Neotropical Sediments and Soils using Cob Phytoliths. J Archaeol Sci 30, 611-627

Pearsall, D.M., Piperno, D.R., Dinan, E.H., Umlauf, M., Zhao, Z., Benfer, R.A. Jr, 1995. Distinguishing Rice (Oryza sativa Poaceae) from Wild Oryza Species through Phytolith Analysis: Results of Preliminary Research. Econ Bot 49, 183-196

Pearsall, D.M., Trimble, M.K. 1984. Identifying Past Farm Activity through Soil Phytolith Analysis: A Case Study from the Hawaiian Islands. J Archaeol Sci 11, 199133

Piperno, D.R. 1985. Phytolith Taphonomy and Distributions in Archaeological sediments from Panama. J Archaeol Sci 12, 247-67

Piperno, D.R. 1988. Phytolith Analysis: an Archaeological and Geological perspective. Academic Press, San Diego

Piperno, D.R. 2006. Phytoliths: a comprehensive guide for Archaeologists and Paleoecologists. Altamira Press, Oxford

Piperno, D.R., Andrews, T.C., Stothert, K.E. 2000. Phytoliths in Cucurbita and other Neotropical Cucurbitaceae and their Occurrence in early archaeological Sites from the Lowland American Tropics. J Archaeol Sci 27, 193-208 
Piperno, D.R., Holst, I., Wessel-Beaver, L., Andres, T.C. 2002. Evidence for the

Control Formation in Cucurbita fruits by the Hard Rind (HR) Genetic Locus:

Archaeological and Ecological Implications. Proc Natl Acad Sci USA. 99, 1092310928

Piperno, D.R., Pearsall, D.M. 1993. Phytoliths in the Reproductive Structures of Maize and Teosinte: Implications for the Study of Maize Evolution. J Archaeol Sci 20, 337-362

Piperno, D.R., Stothert, K.E. 2003. Phytolith Evidence for Early Holocene Cucurbita Domestication in South-west Ecuador. Science 299:1054-1057

Policard, A. 1923. La microincineration des celleles et des tissues. Protoplasm 7, 464481

Raeside, J.D. 1970. Some New Zealand plant opals. New Zeal J Sci 13,122-132

Rosen, A.M., Weiner, S. 1994. Identifying Ancient Irrigation: a New Method using Opaline Phytoliths from Emmer Wheat. J Archaeol Sci 21, 125-132

Rosen, A.M. 1999. Phytolith Analysis in Near Eastern Archaeology in: Meunier, J.D. Colin, F. (Eds.), Phytoliths: Applications in Earth Sciences and Human History, A.A. Balkema Publishers, Lisse, Netherlands, pp, 183-198 
Rosen, A.M. 2005. Phytolith Indicators of Plant and Land Use at Çatalhöyük in:

Hodder I.(Ed.) Inhabiting Çatalhöyük: reports from the 1995-1999 seasons:

McDonald Institute Monographs/BIAA Monograph 39. McDonald Institute for Archaeological Research and British Institute at Ankara, Cambridge and London, pp, 203-212.

Webb, E.A., Longstaffe, F.J. 2002. Climatic Influences on the Oxygen Isotopic Composition of Biogenic Silica in Prairie Grass. Geochim Cosmochim Acta 66, 18911904

Wilding, L.P., Drees, L.R. 1974. Contributions of forest opal and associated crystalline phases to fine silt and clay fractions of soils. Clay Clay Miner 22, 295-306

Zhao, Z., Pearsall, D.M., Benfer, R.A. Jr., Piperno, D.R. 1998. Distinguishing Rice (Oryza sativa Poaceae) from Wild Oryza species through Phytoliths Analysis, II: Finalized method. Econ Bot 52,134-145

Zimmerman, A. 1901. Botanical Microtechnique. Translated from the German by JE Humphrey, Henry Holt, New York 


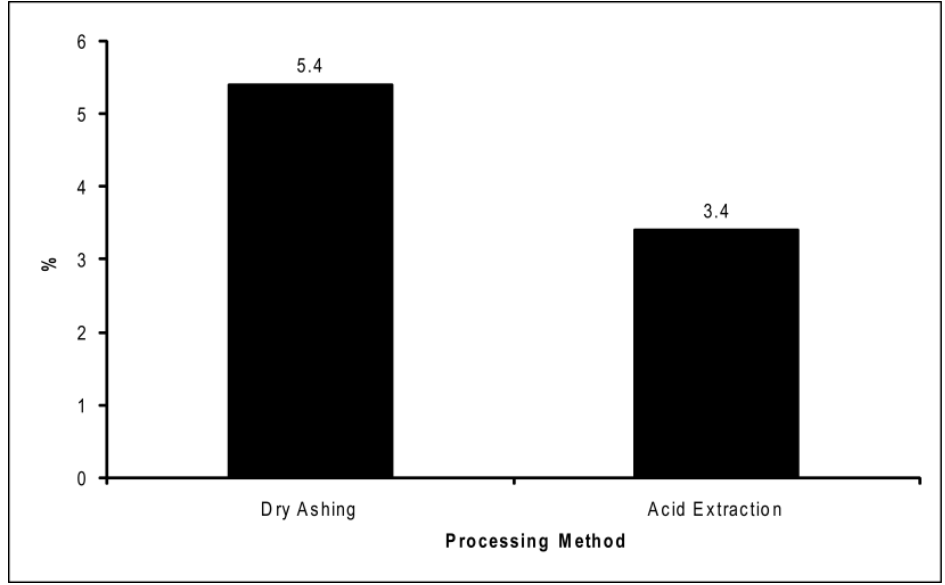

Figure 1 Comparison of the weight percent of the phytoliths to original plant matter from the dry ashed and acid extracted samples
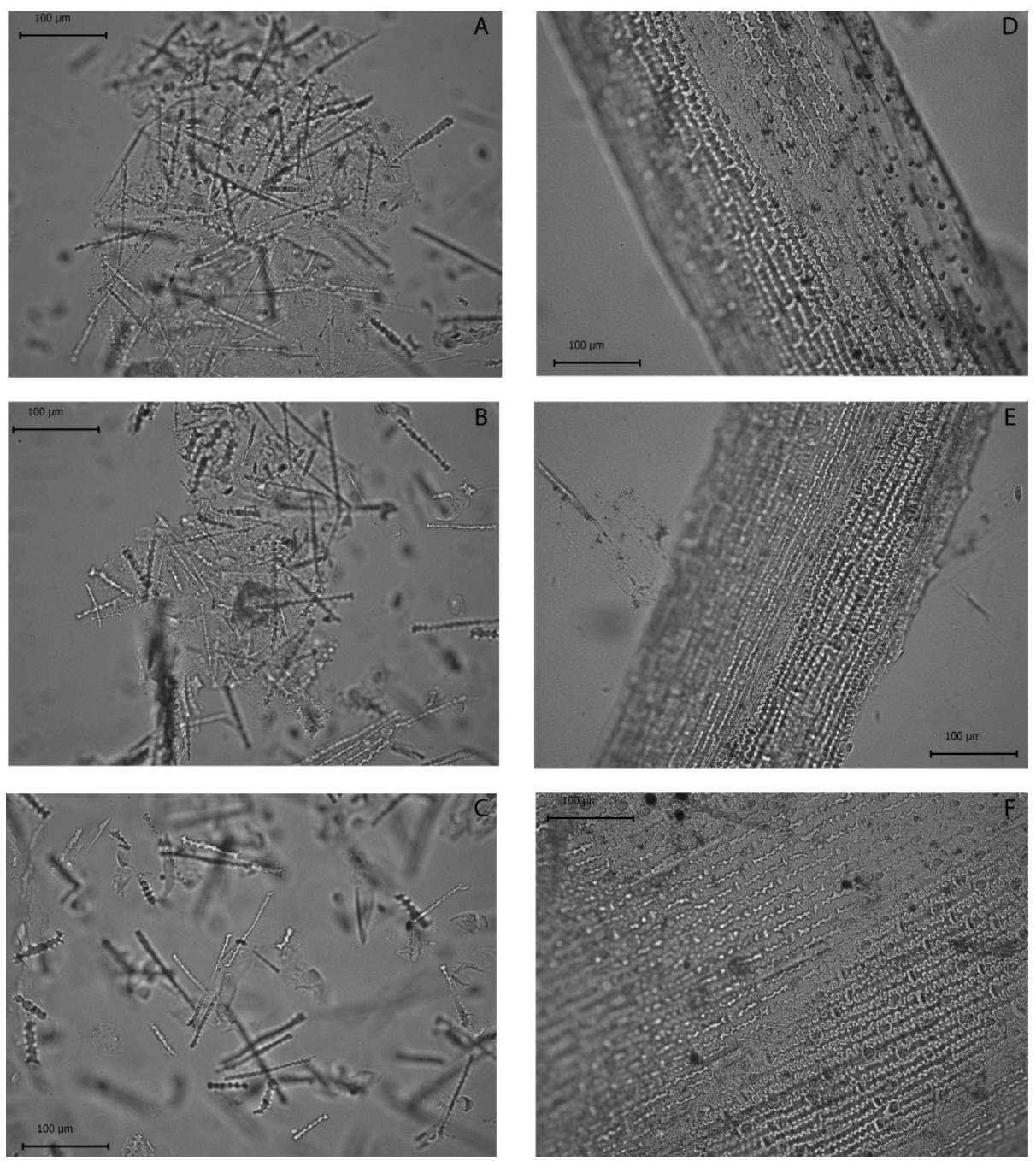

Figure 2 Images of phytoliths produced using the two processing methods: A, B and C are from acid extraction, E, $F$ and $G$ are from dry ashing 


\begin{tabular}{|c|c|c|}
\hline Dry ashing & \multicolumn{2}{|r|}{ Acid extraction } \\
\hline 1) Weigh empty crucibles & 1) & $\begin{array}{l}\text { Weigh out } 0.2 \text { grams of dry plant matter per plant and place } \\
\text { in } 50 \mathrm{ml} \text { centrifuge tube }\end{array}$ \\
\hline $\begin{array}{l}\text { 2) Put dried plant samples in crucibles and weigh } \\
\text { them }\end{array}$ & 2) & Soak plant material for 4 to 5 hours in 20ml of Alcanox $1 \%$ \\
\hline 3) Ash samples in muffle furnace for $3 \mathrm{hr}$ at $500^{\circ} \mathrm{C}$ & 3) & $\begin{array}{l}\text { Discard supernatant, place plant material in a } 500 \mu \mathrm{m} \text { sieve } \\
\text { and rinse with distilled water. }\end{array}$ \\
\hline 4) Transfer ashed samples into centrifuge tube & 4) & Dry in drying cupboard at less than $50^{\circ} \mathrm{C}$ \\
\hline Add $\mathrm{HCl} 10 \%$ (up to $6 \mathrm{ml}$ ) and shake tube & 5) & Transfer sample into $50 \mathrm{ml}$ centrifuge tube \\
\hline 6) Wait $\sim 5 \mathrm{~min}$ & 6) & $\begin{array}{l}\text { Place water bath in fume cupboard and warm bath to near } \\
\text { ebullition point }\end{array}$ \\
\hline $\begin{array}{l}\text { 7) Level samples with distilled water (up to } 10 \mathrm{ml} \text { ), } \\
\text { tighten lid and shake tubes }\end{array}$ & 7) & $\begin{array}{l}\text { Add } 10 \text { to } 15 \mathrm{ml} \text { of concentrated Nitric Acid }\left(\mathrm{HNO}_{3}\right) \text { to } \\
\text { centrifuge tubes (or more if required to cover the whole } \\
\text { sample) }\end{array}$ \\
\hline 8) Centrifuge $5 \mathrm{~min}$ at $2000 \mathrm{rpm}$ & 8) & $\begin{array}{l}\text { Put centrifuge tubes in water bath for } \sim 3 \text { hours (do not close } \\
\text { them, immediately but allow yellow-orange fume to emanate } \\
\text { from tubes first) }\end{array}$ \\
\hline 9) Discard supernatant & 9) & $\begin{array}{l}\text { To speed up digestion, periodically add a pinch of } \mathrm{KClO}_{3} \\
\text { using a spatula (this can react violently, it is best to add very } \\
\text { little, } 2-3 \text { grains, at beginning to observe the reaction) }\end{array}$ \\
\hline 10) Repeat three times & 10) & $\begin{array}{l}\text { Once reaction with the } \mathrm{KClO}_{3} \text { is over, digestion is complete } \\
\left(\mathrm{HNO}_{3} \text { and sample solution is orange/ochre but becomes }\right. \\
\text { yellow when the } \mathrm{KClO}_{3} \text { is added, and reverts to darker orange } \\
\text { after a few minutes. Digestion is complete when } \mathrm{HNO}_{3} \text { and } \\
\text { sample solution is yellow in colour) }\end{array}$ \\
\hline 11) Transfer into weighed beakers & 11) & $\begin{array}{l}\text { Take centrifuge tubes out of water bath and add water up to } \\
40 \mathrm{ml} \text { line and close caps }\end{array}$ \\
\hline 12) Put in drying oven at less than $50^{\circ} \mathrm{C}$ until dry & 12) & $\begin{array}{l}\text { Take the centrifuge tubes out of fume cupboard and } \\
\text { centrifuge for } 5 \text { minutes at } 2000 \mathrm{rpm}\end{array}$ \\
\hline \multirow[t]{3}{*}{ 13) Weigh beakers and sample } & 13) & $\begin{array}{l}\text { Pour off supernatant in fume cupboard sink with the tap water } \\
\text { running abundantly }\end{array}$ \\
\hline & 14) & Carry out 3 washes with distilled water \\
\hline & 15) & $\begin{array}{l}\text { Transfer ashed samples into centrifuge tube and cover with } \\
\mathrm{HCl} 10 \% \text { (up to } 6 \mathrm{ml} \text { ). Close caps and shake tubes }\end{array}$ \\
\hline & 16) & Wait $\sim 5$ min \\
\hline & 17) & $\begin{array}{l}\text { Level samples with distilled water (up to } 10 \mathrm{ml} \text { ), close and } \\
\text { shake }\end{array}$ \\
\hline & 18) & Centrifuge 5 min at $2000 \mathrm{rpm}$, discard supernatant \\
\hline & 19) & Rinse three times in distilled water \\
\hline & 20) & Transfer into weighed beakers \\
\hline & 21) & $\begin{array}{l}\text { Put in drying oven at less than } 50^{\circ} \mathrm{C} \text { until the sample is dry } \\
\text { (over night). }\end{array}$ \\
\hline & 22) & Weigh beakers and sample \\
\hline
\end{tabular}

Table 1 Methodologies used for dry ashing and acid extraction 


\begin{tabular}{|lccc|}
\hline \multicolumn{4}{c|}{ \% of forms in each conjoined category } \\
\hline No of \\
conjoined cells & $\begin{array}{c}\text { Dry } \\
\text { Ashing }\end{array}$ & $\begin{array}{c}\text { Dry Ashing } \\
\text { Acid Extraction }\end{array}$ & $\begin{array}{c}\text { Acid } \\
\text { Extraction }\end{array}$ \\
Single cell & 41.8 & 39.0 & 97.5 \\
$2-5$ & 14.5 & 20.2 & 2.0 \\
$6-10$ & 8.2 & 5.8 & 0.3 \\
$11-15$ & 4.6 & 3.4 & 0.1 \\
$16-20$ & 2.8 & 2.5 & 0.0 \\
$21-30$ & 3.5 & 5.4 & 0.0 \\
$31-50$ & 4.4 & 5.1 & 0.0 \\
$51-70$ & 3.0 & 2.3 & 0.0 \\
$71-100$ & 2.4 & 2.3 & 0.0 \\
$101-150$ & 2.2 & 3.3 & 0.0 \\
$151-200$ & 1.4 & 2.3 & 0.0 \\
$201-250$ & 0.7 & 0.5 & 0.0 \\
$251-300$ & 0.2 & 0.6 & 0.0 \\
$>301$ & 10.2 & 7.2 & 0.0 \\
\hline
\end{tabular}

Table 2 Comparison of the number of conjoined phytoliths found in the assemblages produced by the different processing methods 